\section{think I know that face...}

SIR - Exactly what do we recognize in a face? Intuition suggests that it is the eyes, nose and mouth - they, after all, are what the dictionary uses to define a 'face'. Portraitists labour to get these features right and poets describe the eyes as sure betrayers of identity. Computer scientists, not to be outdone, have designed vision systems that rely on precise measurements or templates of these 'internal' features to recognize faces ${ }^{1}$. This view often seems justified.

But some images, such as the one shown here, suggest that there might be more to face recognition than just an analysis of the internal facial features. The image

\section{IMAGE UNAVAILABLE FOR COPYRIGHT REASONS}

\section{Democrat coalition.}

seems to be a fairly run-of-the-mill picture of the president of the United States, Bill Clinton, and the vice-president, $\mathrm{Al}$ Gore. A closer examination, however, reveals that the two are absolutely identical in terms of the eyes, nose and mouth and their spatial arrangement. (This was arranged by digital manipulation of the original photograph.)

Clearly, in this case, identification rests more on the appearance of the head as a whole than on the internal features alone. (Context is probably also of some significance in this case.) Manipulations with other images point to the same conclusion.

We therefore present this image in support of the idea that, at least on some occasions, the processing performed by the visual system to judge identity is better characterized as 'head recognition' rather than 'face recognition' ${ }^{2-4}$. Artificial

\footnotetext{
1. Proc. Int. Workshop on Automatic Face and Gesture Recognition (ed. Bichsel, M.) (IEEE Computer Soc., 1995).

2. Shepherd, J. W., Davies, G. M. \& Ellis, H. D. Perceiving and Remembering Faces (Academic, London, 1981).

3. Haig, N. D. Perception 13, 505-512 (1984)

4. Fraser, I. \& Parker, D. in Aspects of Face Processing (eds Ellis, H. D., Jeeves, M. A., Newcombe, F. \& Young, A.) (Martinus Nijhoff, Dordrecht, 1986).
}

\section{Tomaso Poggio} non-medical indications. recognition systems might stand to benefit by incorporating, in some measure, the head processing strategy.

\section{Pawan Sinha}

E25-201, Department of Brain and Cognitive Sciences,

Massachusetts Institute of Technology, Cambridge,

Massachusetts 02142, USA

\section{Chinese ethics}

SIR - Since the Chinese Maternal and Infant Health Care Law, previously called the "eugenics and health protection law", was first proposed in December 1993, and finally promulgated on 27 October 1994, it has provoked widespread concern in the international scientific community (see Nature 367, 1-3 \& 372, 123; 1994; 377, 7 \& 378, 594; 1995; 383, 204 \& 569; 1996).

What is the attitude of Chinese geneticists towards ethical issues, including the controversial 'eugenics law'? A national survey, funded in part by the Ethical, Legal, and Social Implications Branch of the US National Center for Human Genome Research, was conducted among 402 geneticists from 30 provinces and autonomous regions in China.

The survey showed that 95 per cent of Chinese geneticists agreed that "people at high risk for serious disorders should not have children unless they use prenatal diagnosis and selective abortion"; 90 per cent agreed with the statement that "an important goal of genetic counselling is to reduce the number of deleterious genes in the population"; and 90 per cent called for ethical guidelines for genetics practice and research in China. Eighty-nine per cent supported current Chinese laws on abortion for genetic abnormalities and

More than half opposed sex selection by any means; 55 per cent thought that gene donors should have a right to share in the profits from commercialized tests or treatments developed from using their genes; and 50 per cent thought that public education on genetics should be the top priority of the Chinese government health budget.

This is the first survey to provide a basis for international discussion on ethics and genetics in China.

\section{Xin Mao}

Division of Genetics,

West China University of Medical Sciences, Chengdu 610041,

People's Republic of China

Present address: Section of Molecular Carcinogenesis, Haddow Laboratories, Institute of Cancer Research, Cotswold Road, Sutton, Surrey SM2 5NG, UK.

\section{Power games in Austrian science}

SIR - The recent debate in Nature about Austrian biomedical research has highlighted several shortcomings but has failed to identify the cause of the problem. I think Austrian science suffers mostly from organizational defects in the university system.

The faculties are run by an oligarchy of committee members who are elected irrespective of their research record. Academic decisions are taken by committees whose voting members consist of 50 per cent professors, 25 per cent academic staff and 25 per cent students. Those eligible for committee work include all professors and a number of student representatives and academic staff delegates who are often reelected for a limitless number of terms. Scientific competence is not a criterion in the election process and hence of low priority in the committee work.

Scientific qualification is evaluated by committee members who lack research competence. Candidates for academic promotion, tenure and professorships are evaluated and selected by delegates who may have no or only a limited record of research performance. The same applies to the allocation of faculty resources, which may be decided by delegates who have never ventured into drafting a research proposal or beyond.

The committee groups favour their members for academic promotion. In the faculty with which I am affiliated, most professorships in the past decade have been awarded to members of the committee oligarchy, with promotion of other candidates from within the faculty or outside the university being rare exceptions. As a result, indifference to science is propagated from the lower to the higher ranks of the faculty.

The committee oligarchy is liable to misuse university resources. Decisions are all too often traded between the committee groups to secure their interests, but are not taken according to objective criteria in the interest of the university.

University funds are distributed irrespective of research performance, because performance in general is not evaluated.

Correction of these shortcomings should be a priority for the Austrian Ministry of Science in its struggle to make our universities fit to compete for European Union research funds. That Austrian science still survives is largely due to the Fonds zur Förderung der Wissenschaftlichen Forschung, the national agency for research funding, which keeps to internationally accepted principles of peer evaluation.

\section{Peter Holzer}

Department of Experimental

and Clinical Pharmacology,

University Medical School,

A-8010 Graz, Austria 